\title{
Prediction of infection after total knee arthroplasty in rheumatoid arthritis patients by evaluating various risk factor
}

\author{
Turkar R. ${ }^{1}$, Vinod P. ${ }^{2}$, Jain S. ${ }^{3}$ \\ ${ }^{1}$ Dr. Rajesh Turkar, Assistant Professor, N.S.C.B. Medical College Jabalpur, ${ }^{2}$ Dr. Vinod Padmanabhan, Chief \\ Orthopaedic Surgeon, SreeSudheendra Medical Mission Hospital, Ernakulum, Kerala, India, ${ }^{3}$ Dr. Siddharth Jain, Senior \\ Resident, CMC, Vellore, India.
}

Corresponding Author: Dr. Siddharth Jain, Senior Resident, CMC, Vellore, India. E-mail: dr.sidrjain@gmail.com

\begin{abstract}
Introduction: Total knee arthroplasty (TKA) is a surgical procedure that provides pain relief and restores function for patients suffering from debilitating arthritis. Despite the overall success of the procedure, periprosthetic joint infection (PJI) is a rare but devastating complication andfound to be a major cause of TKA failure.An infected implant often requires removal, prolonged immobilization and antibiotic treatment and multistage surgery. Hence, prevention of infections in intraoperative and postoperative stage is of paramount importance. Material and Method: We have conducted a retrospective study in SreeSudheendra Medical Mission hospital, Ernakulum, Kerala. We collected the data from April 2014 to March 2018. In this duration we have found 89 cases of rheumatoid arthritis underwent TKA in 148 knees. We have collected and analysed demographic data and information regarding risk factors [like ESR, H/O Diabeties, steroid intake, blood transfusion, preop deformity, preop DMARDs, intraop soft tissue manipulation/finding, Albumin Globulin ratio (A/G)] associate with infection. Postoperatively we have followed our patient for the minimum period of 9 months period to 4 years. Result: We identified DMARDs (esp.methotraxate) and intraoperative manipulation like bone grafting, extra soft tissue release, Z-plasty of tendon as a risk factor for superficial periprosthetic infection ( $\mathrm{P}$ value $<0.05$ ). Diabetes, use of Steroid, Age, Anemia, Blood Transfusion, B/L surgery are not a risk factor for infection ( $\mathrm{P}$ value $>0.05$ ). Conclusion: These results guide our understanding of the relationship between infections and TKA in RA patient, and may help to prospectively identifying high-risk patients, facilitating extra vigilance and implementation of preventive strategies in such patients.
\end{abstract}

Key words: Total knee arthroplasty, Prosthetic joint infection (PJI), Rheumatoid arthritis

\section{Introduction}

Total knee arthroplasty (TKA) is a surgical procedure that provides pain relief and restores function for patients suffering from debilitating arthritis [1]. The number of TKA performed annually has rise in recent years. Despite the overall success of the procedure, periprosthetic joint infection (PJI) is a rare but devastating complication and found to be a major cause of TKA failure [2,3]. Hospital acquired infections in general are a challenging problem for all health care systems. These infections lead to additional suffering and prolonged hospitalization and increased morbidity as well as mortality. Often their treatment requires long term broad spectrum antibiotic. An infected implant often requiresremoval, prolonged immobilizationand antibiotic treatment and multistage surgery.

Manuscript Received: $2^{\text {nd }}$ February 2019

Reviewed: $10^{\text {th }}$ February 2019

Author Corrected: $15^{\text {th }}$ February 2019

Accepted for Publication: $20^{\text {th }}$ February 2019
Hence, prevention ofinfections inintraoperative and postoperative stage is of paramount importance [4-8]. Periodic assessment of wound infection rate and analysis of associated risk factors are crucial stepsto improve future outcome. Although infection occurs less frequently, stillsurgeon strives to minimize these destructive experiences by identifying risk factors those might predispose a patient to develop an infection. One series identified obesity, diabetes, and older age were found to be risk factors for joint Arthroplasty infection $[9,10]$. In some the previous studies, variouscomorbidities were found to increase the likelihood of surgical site infection, included prior open surgical procedures, immunosuppressive therapy, poor nutrition, hypokalemia, diabetes mellitus, obesity, absence of systemic antibiotic prophylaxis, presence of wound drainage longer than 48 hours postoperatively and tobacco use $[11,12]$. 


\section{Original Research Article}

\section{Materials and Methods}

Wehave conducted a retrospective study in SreeSudheendra Medical Mission hospital, Ernakulum, Kerala. We collected the data from April 2014 to March 2018. In this duration we have found 89 cases of rheumatoid arthritis underwent TKA in 148knees. These 89 patients were diagnosed case of rheumatoid arthritis confirmed by rheumatologist of the same institute. We have included the patient suffering from knee arthritis secondary to rheumatoid arthritis aged between 20 to 85 years.

We have excluded patients having primary osteoarthritis or secondary OA to trauma. We have also exclude the patient underwent joint replacement surgery other than knee. One well equipped operation theatre is designated for all orthopaedic procedures. Thus, practically possibilities bacterial cross contamination from other surgical or medical specialities is eliminated. All the Arthroplasties were performed by a senior surgeon. Perioperative antibiotics were used one dose prior and three dose of ivantibiotic postoperatively.

First and second check dress were performed by surgeon himself on $2^{\text {nd }}$ and $4^{\text {th }}$ postoperative day respectively. We have collected and analysed demographic data and information regarding risk factors [like ESR, H/O Diabetes, steroid intake, blood transfusion, preop deformity, preop DMARDs, intraoperative soft tissue manipulation/finding, Albumin Globulin ratio $(\mathrm{A} / \mathrm{G})]$ associate with infection. Postoperatively we have followed our patient for the minimum period of 9 months period to 4 years.

\section{Results}

We have summarized our result in for of table-1

We have analysed the incidence of infection in TKA of Rheumatoid arthritis patient with their pre op biochemical parameters and other predictors of infection, to find whether any co-relation is significant or not.

The minimum age of patient in study group is 22 years andmaximum age is 81 years had TKA. The mean age of patient was $\sim 48$ yrs. Among non-infected group mean age was 56.3years and infected group it was 48.4 yrs. There was no significant statistical variation in age of between infected and non-infected groups. Among total 148TKA, 132 were female and 16 were male. Among them infection seen only in female patients.

There wasno statistically significantdifference found between these group. In the study there were 44 patients, who had DM and rest did not. Incidence is nearly same in both group (DM-6.82\% and non DM 7.69). No statistically significant difference found between two group ( $\mathrm{P}$ value $=0.875)$.

Patients categorized in anemia who had $\mathrm{Hb}<12 \mathrm{gm} \%$. Out of 148 knees who met abovecriteria were 83 and out of those 5 developed infections. Rest 6 infected cases had $\mathrm{Hb}$ above $12 \mathrm{gm} \%$. (P value $=0.673$ ). Steroid use was defined as any form of systemic steroid therapy for $>1$ week in the year before total knee replacement. Among all TKA 43 patients met these criteria and remaining 105 did not.

4 patients among the steroid users developed infection (incidence 9.3\%). Rest 7 of the infected cases were not steroid users. $\mathrm{P}$ value $=0.834$ shows no statistically significant difference between these two group. DMARDs are commonly used to treat rheumatoid arthritis.

Majority of patients were receiving DMARDS preoperatively. Different DMARDs are used fordifferentpatients as decided by our rheumatologist ( $\mathrm{P}$ value $<0.001$ ).33 patients had valgus deformity, 77 patients had varus deformity, whereas 38 patients were neutral. The number of infected cases was 5 in the valgus group, 4 in neutral and 2 in varus group. $(\mathrm{P}$ value $=0.11) .97$ patients required blood transfusion whereas 52 did not.

Among the transfused group 7 patients developed infection and 4 among non-transfused group developed infection. (P value $=0.848$ ). Out of the 149 cases 116 were bilateral cases. Among the bilateral cases 8 got infected. While 3 of the infected were among the unilateral group. ( $\mathrm{P}$ value $=0.926)$. 
Original Research Article

Table-1: Risk factors associated with infections in total knee arthroplasty

\begin{tabular}{|c|c|c|c|c|c|c|c|}
\hline S. No. & Parameter & $\begin{array}{l}\text { Total } \\
\text { TKR }\end{array}$ & $\begin{array}{c}\text { Noninfected } \\
\text { TKR }\end{array}$ & $\begin{array}{l}\text { Infecte } \\
\text { d TKR }\end{array}$ & $\begin{array}{c}\text { Incidenc } \\
\mathrm{e}\end{array}$ & $\begin{array}{c}P \\
\text { value }\end{array}$ & Result \\
\hline \multirow[t]{2}{*}{1} & Age $<=50$ & 26 & 23 & 3 & 11.5 & \multirow[t]{2}{*}{0.64} & \multirow{2}{*}{$\begin{array}{c}\text { No } \\
\text { association }\end{array}$} \\
\hline & Age $>50$ & 122 & 114 & 8 & 6.55 & & \\
\hline \multirow[t]{2}{*}{2} & Male & 16 & 16 & 0 & - & \multirow[t]{2}{*}{0.487} & \multirow{2}{*}{$\begin{array}{c}\text { No } \\
\text { association }\end{array}$} \\
\hline & Female & 132 & 121 & 11 & 8.33 & & \\
\hline \multirow[t]{4}{*}{3} & DMRDsfolitrax & 68 & 64 & 4 & 5.88 & \multirow[t]{4}{*}{$<0.001$} & \multirow[t]{4}{*}{ Association } \\
\hline & DMRDsleflunomide & 10 & 6 & 4 & 40 & & \\
\hline & DMRDs (1+f) & 12 & 12 & 0 & - & & \\
\hline & DMRDs (neither F nor L) & 58 & 55 & 3 & 5.17 & & \\
\hline \multirow[t]{2}{*}{4} & $\mathrm{DM}$ & 44 & 41 & 3 & 6.82 & 0.875 & \multirow{2}{*}{$\begin{array}{c}\text { No } \\
\text { association }\end{array}$} \\
\hline & Non dibetic & 104 & 96 & 8 & 7.69 & & \\
\hline \multirow[t]{2}{*}{5} & Steroid & 43 & 39 & 4 & 9.3 & 0.834 & \multirow{2}{*}{$\begin{array}{c}\text { No } \\
\text { association }\end{array}$} \\
\hline & Not on steroid & 105 & 98 & 7 & 6.67 & & \\
\hline \multirow[t]{2}{*}{6} & $\mathrm{DM}+$ Steroid & 10 & 8 & 2 & 20 & 0.3 & \multirow{2}{*}{$\begin{array}{c}\text { No } \\
\text { association }\end{array}$} \\
\hline & Neither DM nor on Steroid & 61 & 57 & 6 & 9.84 & & \\
\hline \multirow[t]{3}{*}{7} & Deformity Valgus & 33 & 27 & 5 & 15.15 & 0.11 & \multirow{3}{*}{$\begin{array}{c}\text { No } \\
\text { association }\end{array}$} \\
\hline & Deformity Varus & 77 & 73 & 4 & 5.19 & & \\
\hline & Deformity Neutral & 38 & 36 & 2 & 5.26 & & \\
\hline \multirow[t]{2}{*}{8} & $\mathrm{HB}>=12$ & 65 & 59 & 6 & 9.23 & 0.673 & \multirow{2}{*}{$\begin{array}{c}\text { No } \\
\text { association }\end{array}$} \\
\hline & $\mathrm{HB}<12$ & 83 & 78 & 5 & 6.02 & & \\
\hline \multirow[t]{2}{*}{9} & $\mathrm{ESR}>20$ & 113 & 104 & 9 & 7.96 & 0.94 & \multirow{2}{*}{$\begin{array}{c}\text { No } \\
\text { association }\end{array}$} \\
\hline & $\mathrm{ESR}<20$ & 35 & 33 & 2 & 5.71 & & \\
\hline \multirow[t]{2}{*}{10} & $\mathrm{ESR}>50$ & 50 & 45 & 5 & 10 & 0.604 & \multirow{2}{*}{$\begin{array}{c}\text { No } \\
\text { association }\end{array}$} \\
\hline & $\mathrm{ESR}<50$ & 98 & 92 & 6 & 6.5 & & \\
\hline \multirow[t]{2}{*}{11} & CR knee & 28 & 25 & 3 & 10.7 & 0.737 & \multirow{2}{*}{$\begin{array}{c}\text { No } \\
\text { association }\end{array}$} \\
\hline & PS knee & 120 & 112 & 8 & 6.66 & & \\
\hline \multirow[t]{2}{*}{12} & $\begin{array}{l}\text { Blood Transfusion } \\
\text { Required }\end{array}$ & 97 & 90 & 7 & 7.22 & 0.848 & \multirow[t]{2}{*}{$\begin{array}{c}\text { No } \\
\text { association }\end{array}$} \\
\hline & No Blood Transfusion & 51 & 47 & 4 & 7.84 & & \\
\hline \multirow[t]{2}{*}{13} & $\mathrm{~B} / \mathrm{L}$ TKR & 116 & 108 & 8 & 6.9 & 0.926 & No \\
\hline & U/L TKR & 32 & 29 & 3 & 9.3 & & association \\
\hline 14 & A/G Ratio $<1$ & 11 & 10 & 1 & 9.1 & 0.629 & No \\
\hline & A/G Ratio $<1.5$ & 104 & 94 & 10 & 9.6 & & association \\
\hline 15 & Intra op bony procedure & 28 & 26 & 4 & 21 & 0.042 & Association \\
\hline & Intra op soft tissue release & 8 & 5 & 3 & 25 & & \\
\hline
\end{tabular}

In the 148 testssubjects A/G RATIO between 1 and 1.5 had 10 cases of infection. That is more than $90 \%$ of the infected cases had a pre-operative $\mathrm{A} / \mathrm{G}$ ratio between 1 and 1.5 i.e. within normal limits. ( $\mathrm{P}$ value $=0.629)$. Out of 11 infected TKA 9 pt having ESR $>20 \mathrm{~mm}$. If we put cut off mark for ESR 50, out of 98 patients having ESR $<50$, 6 get infected and out of 50 patient having ESR $>50,5$ get infected.

No statistically significant correlation found between disease activity measured by ESR and infection $(\mathrm{P}$ value $=0.604)$. 39 TKA required more than standard soft tissue release and bony cuts (like bone grafting, pie crusting of tight structure, soft tissue release to correct deformity, $\mathrm{Z}$ plasty of tendon etc). Any procedure other than standard soft tissue release and bone grafting having high risk factor for infection $(\mathrm{P}$ value $=0.042)$. Reason could be, increasedsurgical time, more avascular area near surgical field after soft tissue release. 


\section{Original Research Article}

\section{Discussion}

TKR is among the commonest major surgical procedure performed throughout the world currently. Despite continuing efforts toprevent postoperative infections, prosthetic joint infections complicate up to $1 \%$ of primary TKR even in specialized centre [12]. Information on infection incidence in regard to TKR has been analysed from various sources ranging fromsignalcentre studies to large scale multiinstitution studies and national registries.

Rand et al [13] reported that the most important complication affecting the results of total knee replacement in patients with RA is infection. He found rate of infection approximately three times greater in patients with RA than in those with OA.

Improvement in surgical techniques and implant design are continuously being advanced to reduceinfection related complications but the numbers of patients suffering PJI are still high. So it become necessary to know various riskfactors which can play significant role in PJI.

In current study primary TKR infection rate (superficial) was $7.3 \%$, which is a little higher as comparing to previous literature $[14,15]$. Deep infection rate (which require revision surgery) was $0.67 \%$ which was comparable with previous studies. Incidence of infection after TKA hasdeclined from $4.4 \%$ to $1 \%$ after introduction of improved aseptic techniques and routine antibiotic prophylaxis in UK [16]. Some other studies noted PJI rate around $1 \%$ following primary knee replacement in specialized institutions $[17,18]$.

In a study conducted in Finland infection rate after TKA found to be $0.8-0.9 \%$ andrisk of infection found to be increased with increasing age [19,20]. Though in some studieshigher infection rate reported in young age group TKA [21]. But in current study Age was not found to be a risk factor for infection in TKA.

In the current study, $29 \%$ of patients used steroids among which only $10 \%$ of the steroid takers developed infection. That was also not significant $(\mathrm{p}=0.834)$. Some studies in recent pat have reported that use of oral steroid has been shown to increase the risk of infection in TKA $[22,23]$ but other studies revealed no effect of corticosteroids on infected knee replacement [24]. Nevertheless, special precautions need to be taken for the patients who are on steroids. It is not advised to stop steroid use couple of weekbefore elective TKR to overcome risk of infection [25].
In current study $24.8 \%$ patients were diabetic; among the infected group $27.3 \%$ had diabetes. It does not showed any significant association with diabetes and infection in our study $(\mathrm{P}=0.875)$. Other studies have shown direct association between diabetes and increased risk of infection [20,21]. Up to $10 \%$ of patients undergoing knee replacement having diabetes $[22,23]$. Some case series have reported infection rate of up to $7 \%$ [26,27] and in case-control report significantly more kneereplacement infections have been observed with diabetic cases $[11,16,27]$.

In another study in 2011 revealed that, in infected group there weresignificantly more diabetes patients then in non-infected group of lower limb arthroplasty (22\%) [28]. Hence, a strict control of blood sugar levels pre and post operatively is required. A study by Malinzaket al [29] found lower incidence of infection in bilaterally operated cases, but that could be explained on the basis of a selection bias as generally only the relatively healthier patients will be considered and subsequently offered bilateral procedures. Patients having significant co morbidities preoperatively are often not candidates for bilateral procedures. Ritter et al [30] found that bilateral simultaneous knee arthroplasties had superior knee scores yet more phlebitis than unilateral patients. Our study suggests that bilateral knee replacement surgeries having higher incidence (73\%) than unilateral TKR but this data is not statistically significant $(\mathrm{P}=$ 0.926).

Greenky et al [31] suggested that a pre-operative anaemic state was associated with more peri-prosthetic infections. This trend was not seen in our study with almost $55 \%$ of infected patients had a pre-operative $\mathrm{Hb}$ above $12 \mathrm{gm} \%$.

Allogenic transfusion has been proposed as a risk factor for infection in TKA by Pulido et al [32]. Patients receiving allogenic transfusion were 2.1 times more likely to have PJIcompared with patients receiving no transfusion. The association between allogenic transfusion and infection has been reported and relates to the immunomodulation effect of the transfusion [33].

In our study allogenic blood transfusion was associated with increased infection rates as $64 \%$ of the infected patients had received a blood transfusion but statistically no association was found $(\mathrm{P}=0.848)$. Albumin/ Globulin level is a very important index for determining the nutrition status of the patient. The normal $\mathrm{A} / \mathrm{G}$ ratio is $0.8-2.0$. 


\section{Original Research Article}

The $\mathrm{A} / \mathrm{G}$ ratio can be decreased in response to a low albumin or to elevated globulins. Total globulins may be increased in some chronic inflammatory diseases (TB, syphilis), multiple myeloma, collagen disease, and rheumatoid arthritis. Decreased levels are seen in hepatic dysfunction, renal disease and various neoplasm.

In our study we found that there is no correlation between infection and a low $\mathrm{A} / \mathrm{G}$ ratio even though all the patients were having rheumatoid arthritis.

\section{Conclusion}

We identified DMARDs (esp. methotraxate) and intraoperative manipulation like bone grafting, extra soft tissue release, Z-plasty of tendon as a risk factor for superficial periprosthetic infection $(\mathrm{P}$ value $<0.05)$. Diabeties, use of Steroid, Age, Anemia, Blood Transfusion, $\mathrm{B} / \mathrm{L}$ surgery are not a risk factor for infection $(\mathrm{P}$ value $>0.05)$.

These results guide our understanding of the relationship between infections and TKA in RA patient, and may help to prospectively identifyinghigh-risk patients, facilitating extra vigilance and implementation of preventive strategies in such patients. Until now the decline in PJI rate has been achieved by improving the extrinsic factors like operating environment, surgical techniques and introducing antibiotic prophylaxis. But future ways to consider about patient's intrinsic factors which have direct effect on outcome. Multi centre prospective randomized study inlargepopulationwill be neededto allow adequate statistical analysis.

Limitations- The major drawback of this study is small sample size and all data is restricted to one single hospital

Conflict of interest: None declared.

Funding: Nil, Permission from IRB: Yes

\section{References}

1. Bozic KJ, Ward DT, Lau EC, et al. Risk factors for periprosthetic joint infection following primary total hip arthroplasty: a case control study. J Arthroplasty. 2014 Jan;29(1):154-6. doi: 10.1016/j.arth.2013.04.015. Epub 2013 May 20.

2. Maier GS, Horas K, Seeger JB, et al. Is there an association between periprosthetic joint infection and low vitamin D levels? Int Orthop. 2014 Jul;38(7):1499504. doi: 10.1007/s00264-014-2338-6. Epub 2014 Apr 16.
3. Baek SH. Identification and preoperative optimization of risk factors to prevent periprosthetic joint infection. World J Orthop. 2014 Jul 18;5(3):362-7. doi: 10.5312/wjo.v5.i3.362. eCollection 2014 Jul 18.

4. Talbot TR, Kaiser AB. Post-operative infections and antimicrobial prophylaxis. In: Mandell GL, Bennett JE, Dolin R,editors. Principles and Practice of Infectious Diseases, $6^{\text {th }}$ edn. Philadelphia: Churchill Livingstone; 2005. p. 3533 _47.

5. Schwartz T, Agassi M, Peled T. (2000). Prevalence survey ofnosocomial infections in Israeli general hospitals (1997-1998) (Hebrew). Israeli Ministry of Health Report No.4003.

6. Larcom P, Lotke PA. Treatment of inflammatory and degenerative conditions of the knee. In: Dee R, editor. Principles of Orthopedic Practice. New York: McGrawHill Company; 1997. p. 975 _ 7.

7. Schierholz JM, Beuth J. Implant infections: a haven for opportunistic bacteria. J Hosp Infect. 2001 Oct;49 (2):87-93.

8. Lidwell OM. Sir John Charnley, surgeon (1911-82): the control of infection after total joint replacement. J Hosp Infect. 1993 Jan;23(1):5-15.

9. Phillips J, Crane T, Noy M. The incidence of deep prosthetic infections in a specialist orthopaedic hospital a15-year prospective survey. J Bone Joint Surg Br 2006; 88:943-948.

10. Blom AW, Brown J, Taylor $\mathrm{AH}$, et al. Infection after total knee arthroplasty. J Bone Joint Surg Br. 2004 Jul;86 (5) :688-91.

11. Peersman G, Laskin R, Davis J, et al. Infection in total knee replacement: a retrospective review of 6489 total knee replacements. Clin OrthopRelat Res. 2001 Nov; (392):15-23.

12. Kurtz S, Ong K, Lau E, et al. Projections of primary and revision hip and knee arthroplasty in the United States from 2005 to 2030. J Bone Joint Surg Am. 2007 Apr;89 (4):780-5.

13. J A Rand et al. Long-term results of various treatment options for infected total knee arthroplasty. Clinical orthopaedics and related research 248 (1989): 120-128. 


\section{Original Research Article}

14. Parvizi J, Adeli B, Zmistowski B, et al. Management of periprosthetic joint infection: the current knowledge: AAOS exhibit selection. J Bone Joint Surg Am. 2012 Jul 18;94(14):e104. doi: 10.2106/JBJS.K.01417.

15. Scott JD, Forrest A, Feuerstein S, et al. Factors associated with postoperative infection. Infect Control Hosp Epidemiol. 2001 Jun;22(6):347-51.

16. Berbari EF, Hanssen AD, Duffy MC, et al. Risk factors for prosthetic joint infection: case-control study. Clin Infect Dis. 1998 Nov;27(5):1247-54.

17. Parvizi J, Ghanem E, Joshi A, et al. Does "excessive" anticoagulation predispose to periprosthetic infection? J Arthroplasty. 2007 Sep;22(6 Suppl 2):24-8. Epub 2007 Jul 26.

18. Lai K, Bohm ER, Burnell C, et al. Presence of medical comorbidities in patients with infected primary hip or knee arthroplasties. J Arthroplasty. 2007 Aug;22 (5): 651-6. DOI:10.1016/j.arth.2006.09.002

19. Minnema B, Vearncombe M, Augustin A, et al. Risk factors for surgical-site infection following primary total knee arthroplasty. Infect Control Hosp Epidemiol. 2004 Jun; 25(6):477-80.

20. Jämsen E, Nevalainen P, Kalliovalkama J, et al. Preoperative hyperglycemia predicts infected total knee replacement. Eur J Intern Med. 2010 Jun;21(3):196201. doi: 10.1016/j.ejim.2010.02.006. Epub 2010 Mar 15 .

21. Edmonston DL, Foulkes GD. Infection rate and risk factor analysis in an orthopaedic ambulatory surgical center. J SurgOrthop Adv. 2010 Fall;19(3):174-6.

22. Meding JB, Reddleman K, Keating ME, et al. Total knee replacement in patients with diabetes mellitus. Clin OrthopRelat Res. 2003 Nov; (416):208-16. DOI: 10.1097/01.blo.0000093002.90435.56

23. Meding JB, Klay M, Healy A. The pre screening history and physical in elective total joint arthroplasty. $\mathrm{J}$ Arthroplast2007; 22: 21-23.
24. Papagelopoulos PJ, Idusuyi OB, Wallrichs SL. Long term outcome and survivorship analysis of primary total knee arthroplasty in patients with diabetes mellitus. Clin OrthopRelat Res 1996; 330: 124-132.

25. Yang K, Yeo SJ, Lee BP, Lo NN. Total knee arthroplasty in diabetic patients: a study of 109 consecutive cases. J Arthroplasty. 2001 Jan;16(1):1026. DOI:10.1054/arth.2001.19159

26. England SP, Stern SH, Insall JN, et al. Total knee arthroplasty in diabetes mellitus. Clin OrthopRelat Res. 1990 Nov;(260):130-4.

27. Syahrizal A, Kareem B, Anbanadan S. Risk factors for infection in total knee replacement surgery at hospital Kuala Lumpur. Med J Malay 2001; 56: 5-8.

28. Robert A. Malinzak, MD, Merrill A. Ritter, MD, Michael E. Berend, MD, John B. Meding, MD, Emily M. Olberding, MD, and Kenneth E. Davis, MS. Morbidly Obese, Diabetic, Younger, and Unilateral Joint Arthroplasty Patients Have Elevated Total Joint Arthroplasty Infection Rates. The Journal of Arthroplasty Vol. 24 No. 6 Suppl. 12009.

29. Ritter MA, Harty LD, Davis KE, et al. Simultaneous bilateral, staged bilateral, and unilateral total knee arthroplasty. A survival analysis. J Bone Joint Surg Am. 2003 Aug;85-A(8):1532-7.

30. Greenky M, Gandhi K, Pulido L, et al. Preoperative anemia in total joint arthroplasty: is it associated with periprosthetic joint infection? Clin OrthopRelat Res. 2012 Oct;470 (10):2695-701. doi: 10.1007/s11999012-2435-z.

31. Pulido L, Ghanem E, Joshi A, et al. Periprosthetic joint infection: the incidence, timing, and predisposing factors. Clin OrthopRelat Res. 2008 Jul;466(7):1710-5. doi: 10.1007/s11999-008-0209-4. Epub 2008 Apr 18.

32. Raghavan M, Marik PE. Anemia, allogenic blood transfusion, and immunomodulation in the critically ill. Chest. 2005 Jan;127(1):295-307. DOI:10.1378/ chest. 127.1.295

\section{How to cite this article?}

Turkar R., Vinod P., Jain S. Prediction of infection after total knee arthroplasty in rheumatoid arthritis patients by evaluating various risk factor. Surgical Update: Int J surg Orthopedics.2019;5(1):27-32.doi:10.17511/ijoso.2019.i01.05. 